\title{
Promoting critical thinking in higher education in the context of teacher professional development
}

\author{
Amanda R. Franco, Rui Marques Vieira
}

CIDTFF - Departmento de Educação e Psicologia, Universidade de Aveiro, Portugal.

\begin{abstract}
Critical thinking is profusely recognized as a key-skill for today's higher education students, who are simultaneously future employees/employers and forever local-global citizens. Yet, critical thinking must be deliberately, explicitly, and systematically promoted if it is expected to arise and expand. Such a promotion may be stimulated by teachers through the application of strategies that are oriented to critical thinking. Alas, recurrent evidence shows that teachers themselves need teacher professional development on how to do so, seeing that, as a rule, teacher education does not address the promotion of critical thinking open-handedly. With such in mind, the present paper presents a proposal of a teacher continuing professional development program consisting of five two-hour sessions, aimed at enabling university teachers to learn about critical thinking and how to think critically and, in turn, to learn how to teach their students for critical thinking. This program shall be implemented in 2019, with teachers at a public university located in the northern-central region of Portugal. Considerations are made about how the promotion of critical thinking in higher education may be performed via university teacher continuing professional development, bearing in mind the characteristics of this specific public and the principles of teacher professional development itself.
\end{abstract}

Keywords: Critical thinking; higher education; teacher professional development; university teacher continuing professional development; teacher professional development principles. 


\section{Introduction}

Critical thinking (CT) is comprised of capacities, dispositions, knowledge, and criteria, which can be used in everyday life to think reasonably, find explanations, make decisions, and solve challenges (Franco, Vieira, \& Saiz, 2017). Accordingly, it is considered a key-skill today and tomorrow -, say international reports (e.g., OECD, 2015; UNESCO, 2015; World Bank, 2018). Given its broad relevance, which reaches college campus, work world and everyday life (Franco, Vieira, \& Tenreiro-Vieira, 2018), and since there is evidence that thinking can be improved and that it is possible to develop students' CT (Halpern, 2014), one core question arises from that assertion in terms of an educational prospective analysis: How can it be done?

According to the literature (e.g., Nisbett, 2016), the quality of thinking is not a trait fixed at the outset, therefore impermeable to development. On the contrary, the quality of thinking is open to improvement, provided that CT instruction is made available (Halpern, 2014; Saiz, 2018). Notwithstanding, both the emergence and expansion of CT require one fundamental prerequisite: promotion that is deliberate, explicit, and systematic (Franco, Butler, \& Halpern, 2015). CT is essential at any age and at any place, reason why it should be promoted, yet this must be done according to each individual's developmental stage. Indeed, "it is part of good teaching to know where our students are, to meet them there, and then to guide them further along the road" (Edman, 2008, p. 46). In the present paper, we shall focus on the promotion of CT that may be promoted by teachers at school, more specifically, by university professors at the higher education level. Nonetheless, in lieu of focusing on students, it is necessary to focus first on teachers (Janssen et al., 2019), since they will not teach for CT deliberately, explicitly, and systematically without previous teacher professional development.

\section{Critical thinking and teacher professional development}

There are specific strategies that are oriented to the promotion of CT - when implemented deliberately, explicitly, and systematically for that purpose. Using such strategies, teachers can create learning activities that shall enable students to build knowledge and to build on thinking dispositions, abilities, and criteria - the four pillars of CT - in an integrated way (Tenreiro-Vieira \& Vieira, 2014). Yet, before teachers can teach for CT, they are in need of learning how to do so, if they expect to create long-term impacts. Indeed, teacher education does not address, as a rule, the promotion of CT open-handedly (Vieira \& Tenreiro-Vieira, 2016). In the meanwhile, teachers may not have a clear, in-depth, precise understanding of what CT entails (Bezanilla-Albisua, Poblete-Ruiz, Fernández-Nogueira, Arranz-Turnes, \& Campo-Carrasco, 2018). Thus, opportunities for teacher continuing professional development are in need, so teachers may overcome such gaps. The literature suggests that the promotion of teachers' CT is not only possible (Janssen et al., 2019), but that it is 
especially effective when teachers receive such professional development opportunities (Abrami et al., 2008).

With such in mind, the present paper presents a proposal of a teacher continuing professional development program aimed at enabling university professors to learn about CT and how to think critically and, in turn, to learn how to teach their students for CT.

\section{Promoting critical thinking: A proposal of a university teacher continuing professional development program}

The present teacher continuing professional development program was designed in 2018, in light of successful results emphasized in the literature, and shall be implemented in 2019 with teachers at a public university located in the northern-central region of Portugal. Its main goal is to support, supervise, and share with that university's teachers teaching-learning strategies that are oriented to the deliberate, explicit, and intentional promotion of CT. In the long run, this program is aimed at creating impacts on the CT of those teachers' students.

The program includes five two-hour sessions, each one directed at particular goals. Along the program, different strategies oriented to the promotion of CT are presented and practiced - questioning, circle of knowledge, argumentation, constructive controversy, conceptual map, reflexive writing, explain thinking, decision making -, in an alternation between moments for theoretical framing and practical activities (cf. Table 1). Indeed, all activities are preceded by moments of conceptual framing, in order to enable participants to perform all the activities proposed throughout the program.

Table 1. General goals and practical activities of each session in the program.

\begin{tabular}{|c|c|c|}
\hline Session & General goals & Practical activities \\
\hline 1 & $\begin{array}{l}\text { (i) To raise } \\
\text { teachers' } \\
\text { awareness about } \\
\text { the promotion } \\
\text { of CT in the } \\
\text { classroom; } \\
\text { (ii) To stimulate } \\
\text { the reflection } \\
\text { about present } \\
\text { and possible } \\
\text { personal } \\
\text { pedagogical } \\
\text { practices. }\end{array}$ & $\begin{array}{l}\text { (a) In large group, participants are asked to identify the } \\
\text { characteristics that define CT or someone who is a critical thinker. } \\
\text { (b) Each participant is asked to name a concrete example of a } \\
\text { situation in class in which s/he felt that students were not following } \\
\text { or not understanding a certain content and it was necessary to shift } \\
\text { gears. Participants are oriented to explore together what change of } \\
\text { strategy they had to perform in such situations and its impact. } \\
\text { (c) In groups of two people, participants are asked to identify three } \\
\text { pedagogical strategies already used by them and which might foster } \\
\text { the promotion of CT. In large group, participants are asked to share } \\
\text { those strategies, when they were used, and the impact they had. }\end{array}$ \\
\hline
\end{tabular}


2 (i) To connect CT to specific strategies for its promotion;

(ii) To provide practical opportunities for teachers to acquaint with and experience strategies oriented to the promotion of

CT: questioning, circle of knowledge, argumentation, and constructive controversy.

(i) To connect CT to specific strategies for its promotion;

(ii) To provide practical opportunities for teachers to acquaint with and experience (a) Participants are asked to watch an excerpt of the movie "Thank you for smoking" (2005, by Jason Reitman), and to identify which CT abilities and dispositions were evident in the movie, as well as which characters displayed them best. Participants are oriented to reflect on the relevance of CT in daily situations and challenges.

(b) Participants are presented a controversial topic of current social and political affairs (e.g., decriminalization of euthanasia). In small groups, participants are given a newspaper article on that topic (two groups get the same article). Each group is asked to examine their article and to answer a few questions. In large group, each group with the same article is asked to answer those questions; if there are different views on one same article, the elements of the two goups must debate and seek consensus. The elements of the other groups whose article is not yet being discussed must listen activelly and contribute with information/reflexions from their article. The process restarts, this time with the other groups.

(c) Participants are divided in two groups. With reference to a controversial topic (e.g., liberalization of gun licence in the USA), each group is asked to stand in favor or against the topic, regardless of their true standing, and to search for plausible information to sustain their standing, as well as to answer a few questions to prepare their line of argument. Again in large group, each group makes a brief openning statement with arguments in favor of their standing. Following both opening statements, each group must present an argument in favor of its standing, which shall be countered by a rebuttal by the other group. At the end of the ativity, participants are asked to share their true standing on the topic, and if it was hard to stand in favor of/against something they are in fact against/in favor of. They are asked to share if the process of search for information, argumentation, and debate changed/did not change (something about) how they thought about the topic, and why.

(a) Participants are divided into pairs, and asked to build, in light of what they have learned so far, a concept map representing CT (namely, its definition, dimensions, and relevance).

(b) Each participant is given a card containing a quote by a national or international public leader concerning current topics (e.g., the migrants' crisis in Europe; ilegal immigration in the USA), and asked to write a brief essay on it, explaining what is that person's standing on the topic, as well as her/his own. The quote cards are collected and distributed again. Each participant must read her/his new quote, and the participant who had written the essay about that quote must 
strategies

oriented to the

promotion of

CT: concept

map, reflexive

writing, explain

thinking,

decision

making.

4

(i) To raise

teachers'

awareness about

the impact of

personal beliefs

and cognitive

bias on thinking

and behavior;

(ii) To guide

teachers in a

reflection on the

presence and

insidious

influence of

persuasion

techniques

contained in

natural

language.

$5 \quad$ (i) To support

teachers to

create activities

using the

strategies

learned. read it. The participant holding the quote card must activelly listen to the essay, explain in her/his own words its author's standing, and then share her/his own standing.

(c) Each participant is given an article on a controversial topic of current affairs, and asked to fill in a decision-making table to come to a decision. There are two different versions of the question. After comming up with a decision individually, participants are divided into pairs (according to the same formulation of the question), and asked to complete the table once again, after a joint decision-making process. In the large group, each pair is asked to share their decision and its reasons. Also, participants are asked to explain if the decision-making process was easier/more difficult when made in pairs, and how consensus was handled. Participants are also oriented to reflect on the eventual changes in decisions made according to each formulation of the question.

(a) After an activity proposed by Brian Dunning (2012, Your brain sucks), participants are shown how brains tend to create categories to make recovery of information stored in memory easier.

(b) Participants are asked to provide examples of situations in their professional and personal lives that help to illustrate the different cognitive biases and fallacies approached in the session.

(c) Examples of advertisements are distributed, and each participant is asked to examine her/his ad and to reflect if/how could it be considered misleading advertising.

(d) Newspaper articles are distributed. Participants are asked to identify if their article is a fake news or not, and why they think so. After correctly identifying each article, participants are guided on a reflection about how they can assure to access precise information.

(e) Participants are asked to watch an excerpt of The Big Bang Theory TV show, to ignite a debate around barriers to CT.

(f) Participants are asked to sign a petition against dihydrogen monoxide. This activity aims to demonstrate if someone is deceived by this pseudo-scientific request to ban water.

(a) Participants are divided into pairs, so they may have a "critical friend", besides the trainers, with whom to share the process of creating/adapting activities for their own classes, using the strategies oriented to CT that were learned throughout the program. 
At the end of the program, participants are expected to have become prone to autonomously implement such CT friendly strategies in their own practice. At the same time, they should have become able to distinguish facts from opinions, beliefs from knowledge; to identify persuasion techniques conveyed in natural language, as well as fallacies in reasoning; to search for and consider conflicting information; to produce a clear formulation of a complex issue; to identify, analyze, evaluate, and present arguments; among many others.

The program presented here was designed broadly following the principles of teacher professional development, which serve as a set of guidelines on how teacher education and teacher continuing professional development must be delivered. Such principles recommend that teacher professional development must enclose opportunities for collaborative work, a reinforcement of pedagogical content knowledge, a symbiosis between the theoretical and practical dimensions of formation, similarity among the formation and the kind of practices that teachers shall implement themselves in their classes, besides moments for teachers to question, deconstruct, and recreate personal conceptions and practices (Vieira, TenreiroVieira, \& Martins, 2011).

\section{Final considerations}

CT is crucial for today's university students, future employees, and forever local-global citizens. Nonetheless, it must be deliberately, explicitly, and systematically promoted if it is to be developed. Strategies that are oriented to the promotion of CT should be used by teachers, and yet, this possibility is reliant on teachers' previous professional development on how to do so, which not always is accomplished. Moreover, university teachers' ability and will to teach for CT does not improve without difficulty, but rather needs to be supported by formal teacher professional development opportunities, besides further studies about which are the best ways to promote that ability and will (Janssen et al., 2019). To help fill this gap, the program presented here is a possibility on how to do such a previous work with university teachers, so they may learn about CT and how to teach for it.

\section{Funding}

This paper, in the context of the first author's postdoctoral research project (SFRH/BPD/122162/2016), is financially supported by National Funds through FCT Fundação para a Ciência e a Tecnologia, I. P., under the project UID/CED/00194/2019. 


\section{References}

Abrami, P. C., Bernard, R. M., Borokhovski, E., Wade, A., Surkes, M. A., Tamim, R., \& Zhang, D. (2008). Instructional interventions affecting critical thinking skills and dispositions: A stage 1 meta-analysis. Review of Educational Research, 78, 1102-1134.

Bezanilla-Albisua, M. J., Poblete-Ruiz, M., Fernández-Nogueira, D., Arranz-Turnes, S., \& Campo-Carrasco, L. (2018). El pensamiento crítico desde la perspectiva de los docentes universitarios [Critical thinking from the perspective of university teachers]. Estudios Pedagógicos, 44(1), 89-113.

Edman, L. R. O. (2008). Are they ready yet? Developmental issues in teaching thinking. In D. S. Dunn, J. S. Halonen, \& R. A. Smith (Eds.), Teaching critical thinking in psychology: A handbook of best practices (pp. 35-48). West Sussex, UK: Wiley-Blackwell. ISBN: 978-1-4051-7402-2

Franco, A. H. R., Butler, H. A., \& Halpern, D. F. (2015). Teaching critical thinking to promote learning. In D. S. Dunn (Ed.), The Oxford handbook of undergraduate psychology education (pp. 65-74). New York, NY: Oxford University Press. ISBN: 978019-993-381-5

Franco, A. R., Vieira, R. M., \& Saiz, C. (2017). O pensamento crítico: As mudanças necessárias no contexto universitário [Critical thinking: The changes that are needed in the university context]. Revista de Estudios e Investigación en Psicología y Educación, Vol. Extr.(7), A7-012 - A7-016. doi: https://doi.org/10.17979/reipe.2017.0.07.2233

Franco, A., Vieira, R. M., \& Tenreiro-Vieira, C. (2018). Educating for critical thinking in university: The criticality of critical thinking in education and everyday life. Journal for Communication Studies, 11, 2(22), 131-144. eISSN: 1775-352X

Halpern, D. F. (2014). Thought and knowledge: An introduction to critical thinking (5th ed.). New York, NY: Psychology Press. ISBN: 978-1-84872-629-1

Janssen, E. M., Mainhard, T., Buisman, R. S. M., Verkoeijen, P. P. J., Heijltjes, A. E. G., van Peppen, L. M., \& van Gog, T. (2019). Training higher education teachers' critical thinking and attitudes towards teaching it. Contemporary Educational Psychology Advance online publication. https://doi.org/10.1016/j.cedpsych.2019.03.007

Nisbett, R. (2016). Mindware: Tools for smart thinking. London, UK: Penguin Books. ISBN: 978-0-141-97627-3

OECD (2015). Universal basic skills: What countries stand to gain. OECD Publishing. doi: https://dx.doi.org/10.1787/9789264234833-en

Saiz, C. (2018). Pensamiento crítico y eficácia [Critical thinking and efficiency]. Madrid, Spain: Ediciones Pirámide. ISBN: 978-84-368-3944-9

Tenreiro-Vieira, C., \& Vieira, R. M. (2014). Construindo práticas didático-pedagógicas promotoras da literacia científica e do pensamento crítico [Building didactic-pedagogical practices to promote scientific and critical thinking literacy]. Documentos de Trabajo de Iberciencia, 2. Madrid, Spain: Iberciencia.

UNESCO (2015). Rethinking education - Towards a global common good? Paris, France: UNESCO. Retrieved November 29, 2018, from http://unesdoc.unesco.org/images/0023/002325/232555e.pdf 
Vieira, R. M., \& Tenreiro-Vieira, C. (2016). Teaching strategies and critical thinking abilities in science teacher education. In G. Gibson (Ed.), Critical thinking: Theories, methods and challenges (pp. 77-97). New York, NY: Nova Science Publishers. ISBN: 978-1-63484349-2

Vieira, R. M., Tenreiro-Vieira, C., \& Martins, I. P. (2011). A educação em ciências com orientação CTS [Science education with a CTS orientation]. Porto, Portugal: Areal Editores. ISBN: 978-989-647-352-5

World Bank (2018). World development report 2018: Learning to realize education's promise. Washington, DC: International Bank for Reconstruction and Development / The World Bank. doi: 10.1596/978-1-4648-1096-1 